\title{
Differences in physical activity and nutrition- and silhouette-related behaviours in male and female students in selected European countries
}

\author{
Barbara Bergier ${ }^{1, A-F}$, Józef Bergier ${ }^{1, A-D, F}$, Ewelina Niźnikowska ${ }^{1, A-D, F}$, Ján Junger ${ }^{2, A-C, F}$, \\ Ferdinand Salonna ${ }^{3, A-C, F}$, Pongrác Ács ${ }^{4, A-C, F}$, Karel Frömel ${ }^{3, A}$ \\ 1 Pope John Paul II State School of Higher Education, Biala Podlaska, Poland \\ 2 Pavol Jozef Šafárik University, Kosice, Slovak Republic \\ ${ }^{3}$ Palacký University, Olomouc, Czech Republic \\ ${ }^{4}$ University of Pécs, Hungary \\ A - Research concept and design, B - Collection and/or assembly of data, C - Data analysis and interpretation, \\ $D$ - Writing the article, $E$ - Critical revision of the article, $F$ - Final approval of article
}

Bergier B, Bergier J, Niźnikowska E, Junger J, Salonna F, Ács P, Frömel K. Differences in physical activity and nutrition- and silhouette-related behaviours in male and female students in selected European countries. Ann Agric Environ Med. 2018; 25(1): 176-181. 10.26444/aaem/80988

\begin{abstract}
As indicated by the $\mathrm{WHO}$, lifestyle plays a unique role in human health, which in turn is determined to a great extent by physical activity and nutrition. It must be borne in mind that physical activity should be systematic and regulated by an age-appropriate exercise intensity. All this indicates that learning about students' lifestyle, with a particular focus on physical activity is vital as it these young people who aspire to the role of the future elites.

Objective. The aim of the study is to evaluate the level of physical activity, nutrition- and silhouette-related behaviours of male and female students to assess the relationships between these variables in students from the Visegrad Group countries. Materials and method. The study was conducted in 2015 and involved 2,497 students attending three undergraduate levels aged $-\bar{x}-21,76$, (SD-1,80) - 1,211 males (48.5\%) and 1,286 females (51.5\%). The IPAQ long-form and a questionnaire by the Polish Chief Sanitary Inspector were used.

Results. Physical activity was significantly higher in male than female students. An important relationship was observed among the larger number of consumed meals, level of physical activity, and silhouette-related behaviours in male students, which was not the case with females. However, there was an important correlation between physical activity in males and females who exercised to increase or decrease body weight (musculature), and took medications to increase body weight (musculature).

Conclusion. Both males and females showed pro-health attitudes related to the level of physical activity and nutrition-and silhouette-related behaviours.
\end{abstract}

Key words

students, physical activity, IPAQ-L, nutrition-related behaviours, silhouette-related concerns

\section{INTRODUCTION}

It is commonly emphasised that taking regular exercise and observing the principles of adequate nutrition are essential health-promoting behaviours. According to the WHO, rational physical activity is considered as one of the pro-health behaviours $[1,2]$. Besides, maintaining optimum physical activity affects the necessary body systems positively $[3,4,5]$. The other significant factor influencing health is a sensible diet [6].

Despite many illnesses resulting from improper nutrition, the European Commission estimates that most European citizens assess their diets as appropriate [7].

Unhealthy diet results in obesity, which is defined as the greatest health hazard of the 21st century. According to the WHO, in 2014 alone, the incidence of obesity doubled, compared with 1980 [8].

The current study presents the issue of nutrition focusing on eating habits - the quality of food and frequency and forms of consumption, which are shown in time perspective.

Address for correspondence: Józef Bergier, Pope John Paul II State School of Higher Education in Biala Podlaska, Sidorska 95/97, 21-500 Biała Podlaska, Poland E-mail: rektor@pswbp.pl

Received: 20.10.2017; accepted: 05.12.2017; first published: 2018.01.05
It is considered that by following the strict rules of the abovementioned behaviours it is possible, to a large extent, to prevent the significant contemporary civilisation problem, i.e. becoming overweight and consequently obese.

University adolescents form a specific social group which, on the one hand, has greater opportunities for acquiring knowledge, including the importance of the healthpromoting lifestyles and, on the other hand, is exposed to some negative factors such as irregular meals, irregular lifestyles, and relatively low physical activity levels. Therefore, it seems significant to raise the problem concerning healthy lifestyle in this particular social group.

It is disturbing to find that the level of physical activity of students, the future elite, is low, which is evidenced by studies conducted on various continents $[9,10,11,12,13]$. Favourable results concerning physical activity are rare, as is the case with American students, who showed an overall high level of physical activity [14]. A similar phenomenon was observed among students from India [15]. Further, there is a general belief that the level of physical activity of students in medical specialities is unsatisfactory $[16,17,18,19]$. Eating behaviours in students coming from different countries appear even less favourable [19, 20, 21, 22, 23, 24, 25, 26, 27]. 
Health-related behaviour publications typically deal with one type of behaviour, as is the case with physical activity $[28,29,30]$, or eating habits [31]. However, a new trend has appeared, i.e. searching for correlations between students' physical activity and nutrition-related behaviours [32, 33, 34, $35,36]$. In turn, research concerning the association between physical activity and evaluation of own silhouette is rarely conducted, and most often pertains to the BMI index [20, $37,38,39]$.

\section{OBJECTIVE}

The most significant aim of the study, which is vital both for theoretical and practical considerations, concerning students' life, was to undertake research that would look for relationships within three health-related behaviours (physical activity, dietary behaviour, self-esteem) in male and female students. There also arose questions concerning the health behaviours of students coming from the European countries which have recently joined the free market economy, and the increasing quality of democratic standards in the lives of their citizens.

\section{MATERIALS AND METHOD}

The study was conducted in 2015 and covered 2,497 students from the Visegrad Group of countries (Czech Republic, Poland, Slovakia and Hungary) attending all three undergraduate levels, aged $-\bar{x}-21,76($ SD-1,80) - 1,211 males (48.5\%) and 1,286 females (51.5\%). Due to incomplete questionnaire replies, the final analysis was based on the data provided by 2,237 students - 1,068 males (47.7\%), i.e. 219 from the Czech Republic, 356 - from Poland, 262 - Slovakia, and 231 - Hungary, as well as 1,169 females (52.3\%). i.e. 284 from the Czech Republic, 371 - Poland, 250 - Slovakia and 264 - Hungary.

The study method was the long-form of the International Physical Activity Questionnaire (IPAQ-L), and a questionnaire on health-related behaviours devised by the Chief Sanitary Inspector in Poland.

The statistical analysis, i.e. arithmetic means of individual indices, was calculated using STATISTICA v.10. When comparing particular variables concerning quantitative questions, the Mann-Whitney U and Kruskall Wallis tests were applied, while statistically significant differences concerning the nominal scale values were measured with the Pearson Chi-squared test. In all the analysed cases, the statistically significant difference was assumed for $\mathrm{p}=0.5$.

Analysis of the results - Condition and level of physical activity. The level of total physical activity of all students (males and females) was 5,588.5 MET-min/week). Males exhibited a far higher level of total physical activity - 6,023.9 MET-min/week, when compared to females - 5,190.6 METmin/week ${ }^{*}$, (Fig. 1; Tab. 1).

According to the current classification, there are three physical activity levels distinguished by IPAQ: a) high, which exceeds 3,000 MET-min/week, or 1,500 MET-min/ week, if it involves vigorous activities; b) moderate, which concerns activity over $600 \mathrm{MET}$-min/week; and c) low below $600 \mathrm{MET}-\mathrm{min} /$ week $^{\star *}$. The surveyed students showed
Table 1. Differences in domains of physical activity according to gender Mann-Whitney $U$ test

\begin{tabular}{|c|c|c|c|c|}
\hline \multirow[b]{2}{*}{ Domain of activity } & \multicolumn{2}{|c|}{ Rank sum } & \multirow[b]{2}{*}{ Z } & \multirow[b]{2}{*}{$\mathrm{p}$} \\
\hline & $\begin{array}{c}\text { Male } \\
\text { students }\end{array}$ & $\begin{array}{l}\text { Female } \\
\text { students }\end{array}$ & & \\
\hline Total activity & 1244739 & 1258465 & 3.31 & $0.0009 *$ \\
\hline Activity at work & 1200894 & 1302310 & 0.38 & 0.7029 \\
\hline Mobility & 1158013 & 1345191 & -2.43 & $0.0150 *$ \\
\hline Household activity & 1256333 & 1246871 & 4.02 & $0.0001 *$ \\
\hline Sports activity & 1237051 & 1266152 & 2.75 & $0.0060 *$ \\
\hline
\end{tabular}

"significant differences at $\mathrm{p}<0.05$

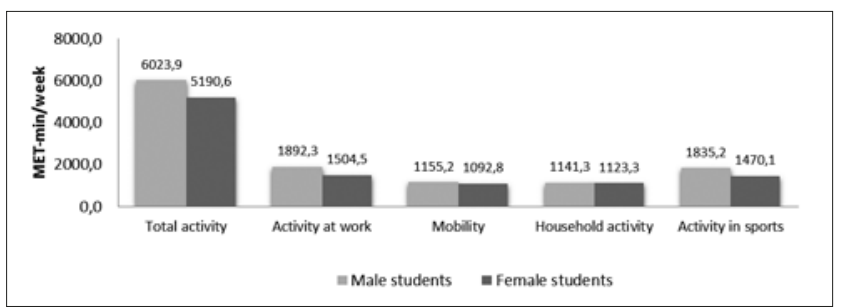

Figure 1. Domains of physical activity according to gender

a satisfactory level of physical activity as the majority (50.2\%) were in the highest band (high level); $40.7 \%$ showed a moderate level, and only $9.0 \%$ displayed a low level of physical activity.

Nutrition-related behaviours. The most significant number of meals consumed by both male and female students was four per day, i.e. $39.6 \%$ and $43.1 \%$, respectively. No significant differences in the number of consumed meals were observed within individual genders (Fig. 2). However, significant gender-related differences were found concerning the proportion of main meals.

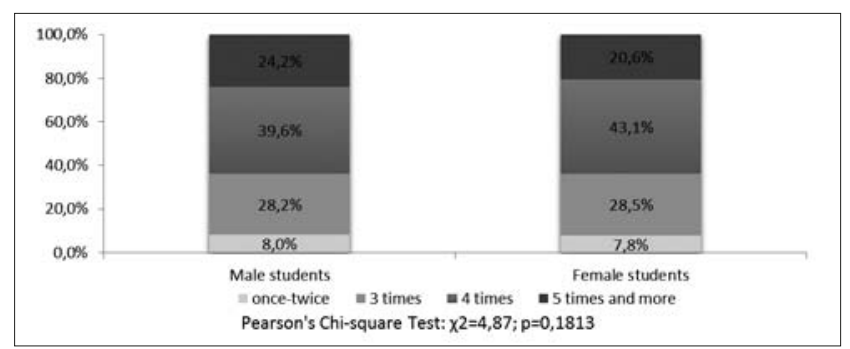

"significant differences at $\mathrm{p}<0.05$

Figure 2. Mean number of meals consumed daily by male and female students in the study

For the majority of female and male students, the main meal was dinner (60.4\% and $64 \%$, respectively), which was followed by breakfast $-35.5 \%$ and $23.5 \%$. Supper turned out to be relatively insignificant, as it accounted for just $4.1 \%$ of the meals in female and $12.4 \%$ in male students (Fig. 3).

The analysis of the relationship between the level of physical activity and the number of the consumed meals confirmed a significant correlation in males, who overall had more meals. The relationship was the highest in those who consumed five or more meals per day (Fig. 4).

Significant correlations were also found between the level of physical activity and the main meals (breakfast, dinner, supper). Both in the case of males and females, higher values 


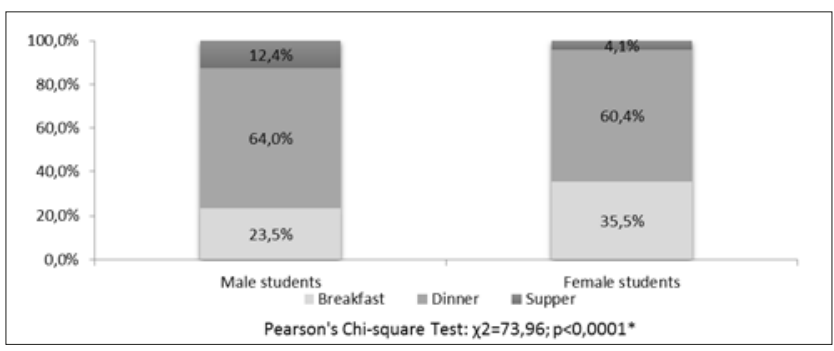

"significant differences at $\mathrm{p}<0.05$

Figure 3. Main meal of male and female students in the study

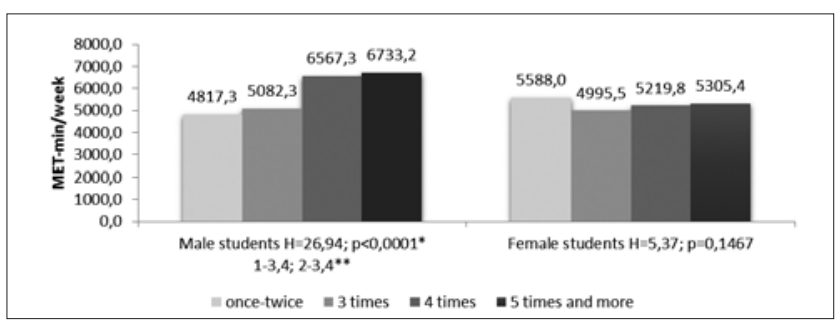

"significant differences at $\mathrm{p}<0.05$

**number of meals consumed with significant differences observed at $p<0.05$

Figure 4. Level of total physical activity of male and female students with consideration of the mean number of meals consumed daily

of the level of physical activity were observed when breakfast was the main meal, i.e. 7,470.8 MET in males, and 5,461.9 MET in females (Fig. 5).

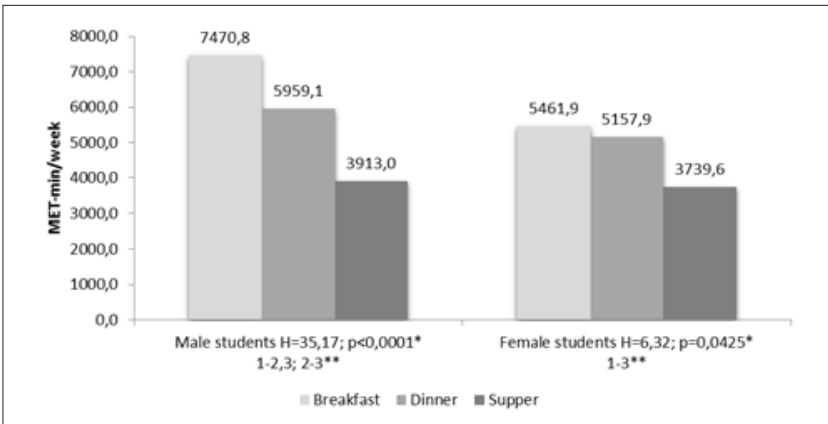

Figure 5. Level of total physical activity of male and female students with consideration of the main meal

* The term 1 MET refers to metabolic equivalent, a unit used to estimate oxygen consumption at rest: $3.5 \mathrm{ml}$ of oxygen $/ \mathrm{kg}$ body weight per minute.

** In the section below, the abbreviated term MET will be used.

Willingness to lose weight. The desire to lose weight was manifested by $42.9 \%$ of males and $70.3 \%$ of females. The relationship between the total level of activity in male students who expressed their willingness to lose weight $(6,005.3 \mathrm{MET})$ and those who did not wish to do so $(6,071.2 \mathrm{MET})$ was statistically insignificant (Fig. 6). A similar regularity, a lack of significance, was confirmed in the group of females (Fig. 7), although it should be mentioned that the total physical activity was slightly higher among females who wanted to lose weight (5,316.0 MET), compared to those who did not show such intentions $(4,968.7 \mathrm{MET})$.

Willingness to gain weight (musculature). Willingness to gain weight was expressed by $39.9 \%$ of male and $20.6 \%$ of female students. The level of physical activity in males who wished to gain weight was significantly higher $(7,562$ MET) (Fig. 8). No such relationship was found in the group of females who expressed the desire to gain weight (Fig. 9).

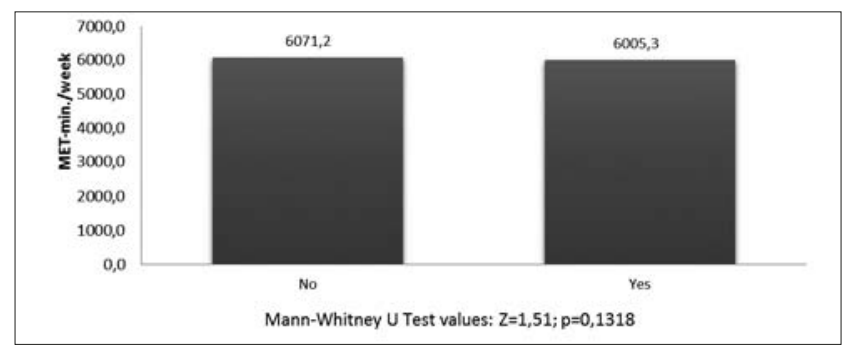

Figure 6. Total physical activity level of students with regard to their willingness to lose weight

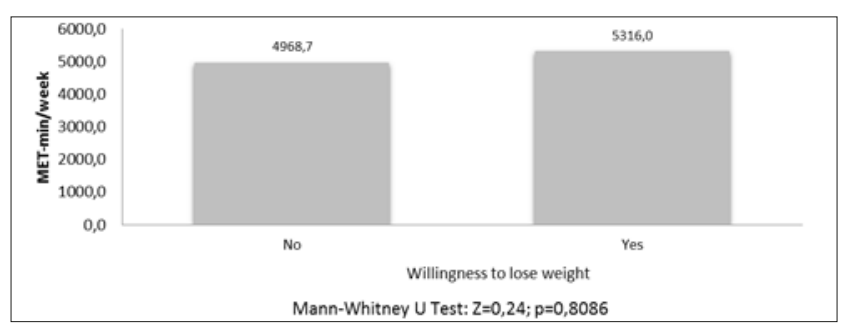

Figure 7. Level of total physical activity of female students with consideration of willingness to gain weight

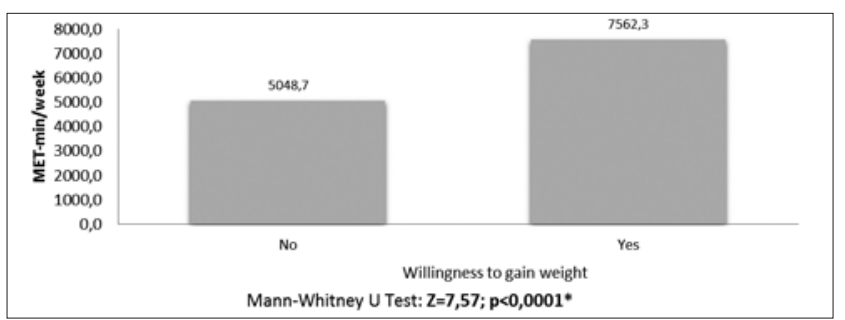

"significant differences at $\mathrm{p}<0.05$

Figure 8. Level of total physical activity of male students with consideration of willingness to gain weight

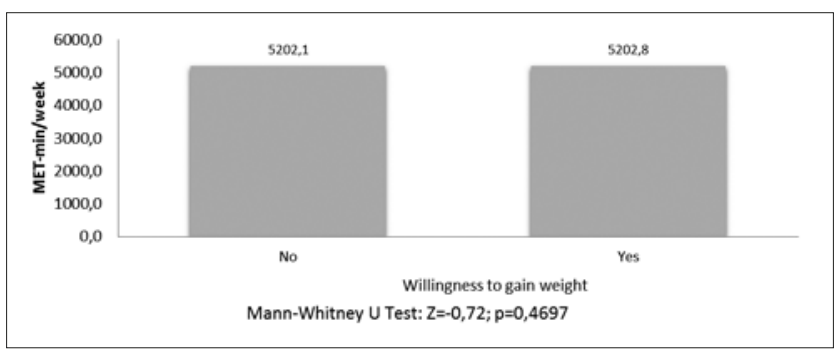

Figure 9. Level of total physical activity of female students with consideration of willingness to gain weight

Measures taken to improve silhouette. To improve their silhouette, males mainly performed physical exercises to increase their body weight (musculature) $-43.5 \%$, or to decrease body mass $-32.8 \%$. For this purpose, they also consumed medications for body-weight gain $-10.6 \%$, and, to a smaller degree, weight-loss drugs $-4.2 \%$. The percentage of other measures was low and remained within the range of $1 \%$ (Fig. 10).

Female students, to improve their silhouette, also mainly performed exercises to lose body weight $-56.3 \%$, and, to a lesser extent, engaged in workout to gain weight (musculature) $-21.5 \%$, or took weight loss-drugs $-7.0 \%$. Other medicinal products were also recorded but in a minimum percentage (Fig. 11).

Among males, a significant correlation was found between the level of total physical activity and adequate workout 


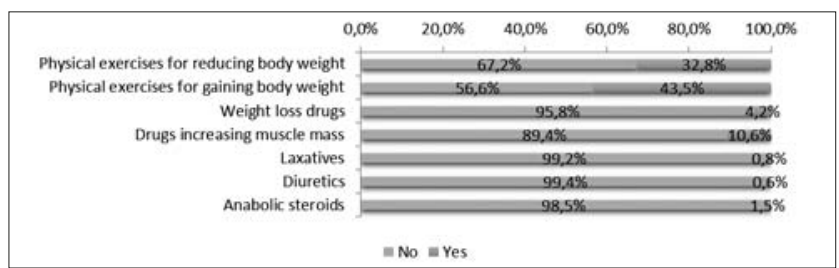

Figure 10. Measures applied by students to improve silhouette

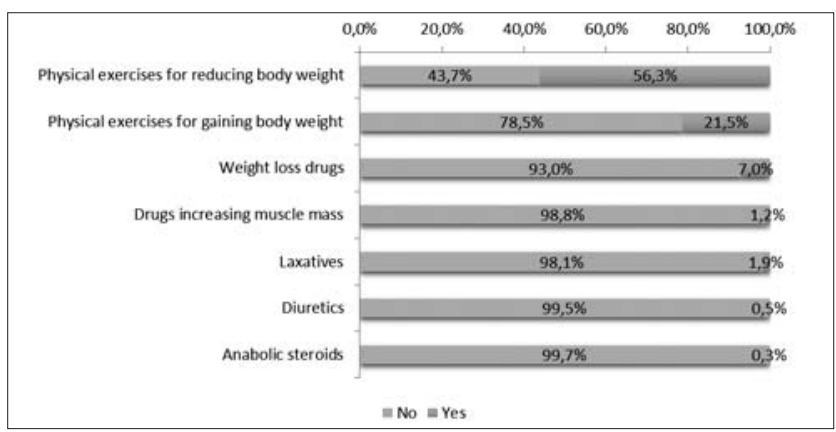

Figure 11. Measures applied by female students to improve silhouette

to reduce body weight, with the value of physical activity amounting to 7,439.9 MET. Such a correlation was also visible in the case of weight gain (musculature) exercises, with the total level of physical activity - 7,865.8 MET (Fig. 12). Also in females, a significantly higher level of total physical activity was observed in the group performing weight gain (musculature) exercises- 6,793.4 MET, and in those taking body weight reduction exercises - 5,923.9 MET-min/week, and drugs for increasing muscle mass - 8,863.3 MET (Fig. 13).

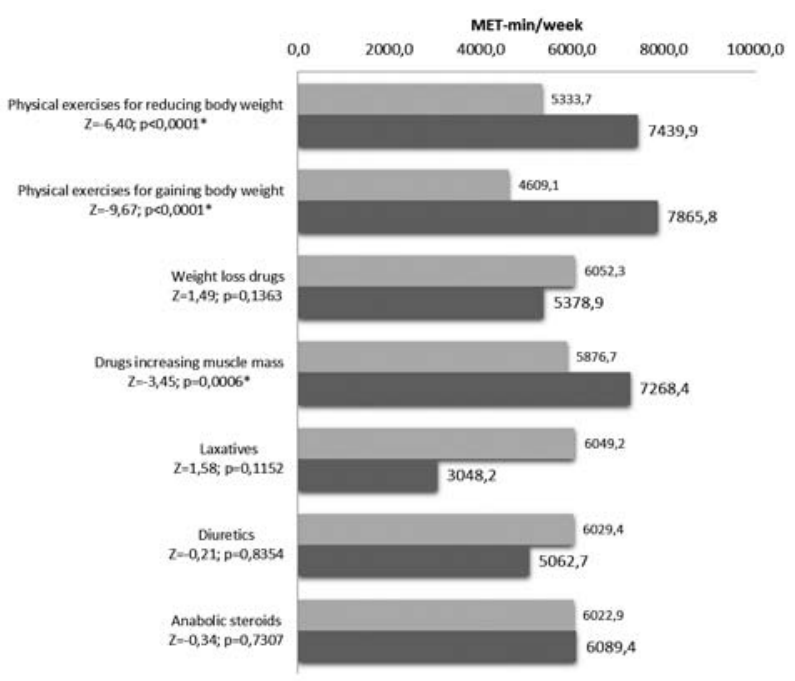

$\equiv$ No $\equiv$ Yes

"significant differences at $\mathrm{p}<0.05$

Figure 12. Level of total physical activity of male students with consideration of measures applied to improve silhouette

The opposite correlation was confirmed in females who used diuretics because their level of physical activity was significantly lower, i.e. 1.698,2 MET (Fig. 13). However, it should be noted that only $1.2 \%$ of the female students resorted to those means to increase muscle mass.

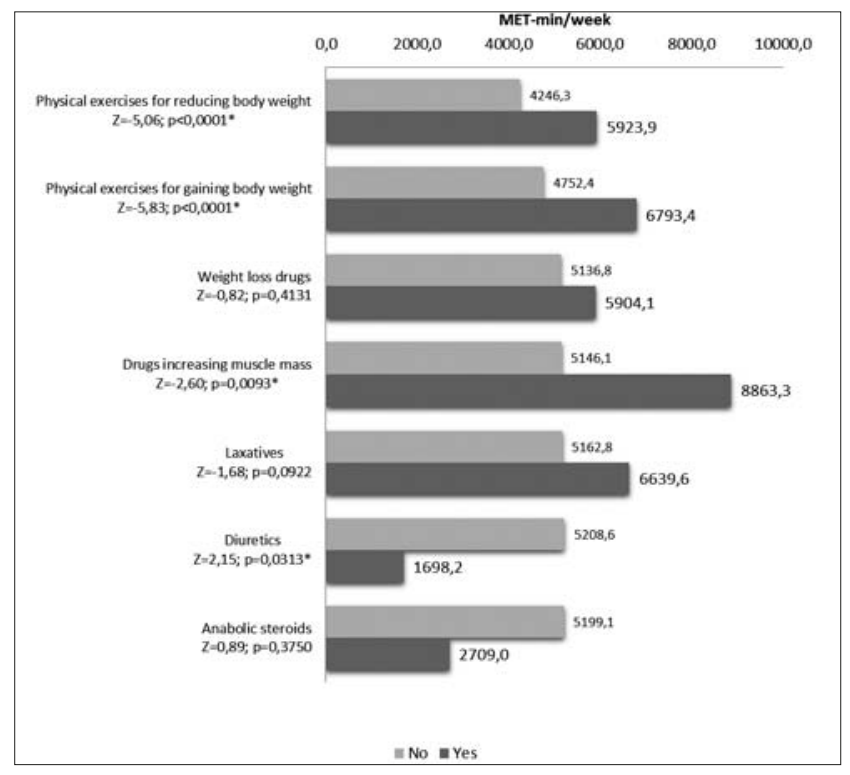

"significant differences at $\mathrm{p}<0.05$

Figure 13. Level of total physical activity of female students with consideration of measures applied to improve silhouette.

\section{DISCUSSION}

The use of a standardised procedure as a method of carrying out research seems very important in the debate of specific phenomena. The International Physical Activity Questionnaire (IPAQ) created such an opportunity and enabled the evaluation of physical activity among the surveyed students. The obtained data from this questionnaire allowed for a positive evaluation of the general level of physical activity of the examined students, of whom just over a half (50.2\%) were characterised by a high level of physical activity, $40.7 \%$ moderate and $9.0 \%$ low activity. The mean value was $5588 \mathrm{MET}$-min/week, which was higher when compared to those described in numerous studies conducted in different countries $[9,10,11,12]$. Thus, the results of the surveyed students contrast positively with the evaluation shown in many other reports, which is disturbing.

The research conducted to-date indicates the almost universal phenomenon of higher physical activity in males students than in the females $[33,38,40]$, which is also confirmed by the results of the presented study.

A particularly interesting phenomenon in physical activity is the study of its correlation with nutritional behaviour $[23,26,27,32,33,34,35]$. The majority of the previously conducted studies concerning students' nutrition-related behaviours reveal many abnormalities $[27,41,42]$. In the case of the examined students, a positive trend in health-related behaviours may be observed, which is evidenced by the fact that the largest number of meals consumed by students of both genders was four per day, which corresponds to the standards adopted in Poland [43]. It is also worth noting that the main meal both for male and female students was dinner, which accounted for more than $60 \%$ of the three primary meals. Other noteworthy relationships concerned a higher level of physical activity of the examined students who consumed more meals per day, including breakfast, which was the main meal for both genders. It is significant that the research shows differences between males and females 
regarding these correlations, which was also evidenced by other studies [27, 41, 44].

Considering the examined students (males and females) from the Visegrad Group ofr countries, no significant relationships were found between the level of physical activity and willingness to lose weight. Likewise, such a correlation with physical activity was not observed in females who expressed a desire to gain weight (musculature). However, such an association was found in male students. Further, there was a positive phenomenon showing that both males and females, to improve their figure, mainly performed exercises with the intention of reducing and increasing their weight (musculature). Also, in both genders, there were shown significant correlations between the level of physical activity and the use of exercise to increase and decrease weight (musculature). Similar results were obtained in Ukrainian students regarding exercises performed to lose body weight [32], and the female students who engaged in workout to gain or reduce weight (musculature) [45].

Analysis of the level of physical activity and its relationships with nutrition-related behaviours, as well as behaviours associated with silhouette-related concerns among the examined male and female students, presents a favourable image of their pro-health lifestyles in caring for the silhouette. This favourable diagnosis is of particular importance for the European countries that have joined the free market economy in the recent years, which enables the examined students from Eastern Europe to enhance their development and sophistication.

\section{Acknowledgements}

Research was conducted in the framework of the project "Physical and recreational activity and eating habits of the youth from the V4 countries", co-financed from the funds of the Visegrad Fund.

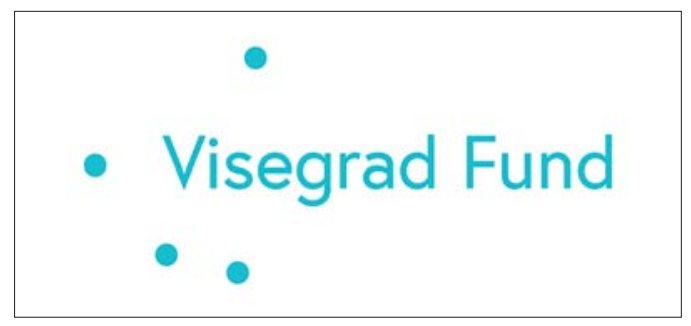

\section{CONCLUSIONS}

1. Male and female students were characterised by a high level of physical activity, with significantly higher values in males, both regarding total physical activity and its domains such as work/education, household activities and sports activities.

2. Among male students, a significant association was found between a higher level of physical activity and a larger number of consumed meals, while no such relationship was observed among females.

3. In both genders, a significant relationship was noted between the level of physical activity and different means of improving the silhouette with regard to gain and reduce weight exercises (musculature).

\section{REFERENCES}

1. World Health Organization: WHO Mortality Database - 1st May 2013 update. WHO Department of Health Statistics and Information Systems, Geneva 2013, [access: 10.05.2015], http://vvTVW. WorldHealthOrganization.mt/heaIthmfo/statistics/mortality_ rawdata/en/index.h tml

2. World Health Organization: Global status report on noncommunicable diseases 2014. WHO, Geneva 2014.

3. Colman GJ, Dave DM. Physical activity and health (No. wl8858). National Bureau Econ Res. 2013. doi: 10.3386/wl8858

4. Humphreys BR, McLeod L, Ruseski JE. Physical activity and health outcomes: evidence from Canada. Health Economics. 2014; 23(1): 33-54.

5. Neufer PD, Bamman MM, Muoio DM, Bouchard C, Cooper DM, Goodpaster BH. Understanding the cellular and molecular mechanisms of physical activity-induced health benefits. Cell Metabolism. 2015; 22(1): 4-11.

6. World Health Organization: Obesity and overweight. Factsheet [access: 07.12.2015] n311.WHO,Geneva2015, http://www. WorldHealthOrganization.int/mediacentre/factsheets/fs311/en/

7. Komisja Europejska: Eurobarometer 64.3 Health and food. European Comission, Brussels 2006.

8. World Health Organization: Noncommunicable diseases. Fatctsheet. WHO, Geneva 2015, http://www.WorldHealthOrganization.int/ mediacentre/factsheets/fs355/en/

9. Pengpid S, Peltzer K. Physical inactivity and associated factors among university students in South Africa. African J Phys Health Educ Recreat Dance (AJPHERD). 2013; 19(1): 143-153.

10. Baar J, Romppel M, Igel U, Brahler E, Grande G. Associations Between the Residential Environmental and Physical Activity in German College Students and the Role of Self-Efficacy as a Mediator. Selbstwirksamkeitserwartung als Mediator der Zusammenhange von Wohnumgebung udn körperlicher Aktivitat Studierender. Zeitschrift für Gesundheits-psychologie. 2014; 3: 118-128.

11. Tsos A, Oliynyk O, Szepeluk A. Subjective health profiles among the Ukrainian school youth from medical school. Health Problems of Civilization. 2016; 10(1): 32-38. doi:10.5114/hpc.2016.58206

12. Haase A, Steptoe A, Sallis JF, Wardle J. Leisure-time physical activity in university students from 23 countries: Associations with health beliefs, risk awareness, and national economic development. Prev Med. 2004; 39(1): 182-190. doi:10.1016/j.ypmed.2004.01.028

13. Hoyos I, Irazust A, Gravina L, Gil S. M, Gil J, Irazusta J. Reduced cardiovascular risk is associated with aerobic fitness in university students. Eur J Sport Sci. 2011; 11(2): 87-94.

14. Chiang L, Zhang P, Casebolt K. A Comparison of College Students' Physical Activity Levels between Taiwan and the United States. Asian J Exer Sports Sci. 2013; 10(2): 49-60.

15. Padmapriya K, Krishna P, Rasu T. Prevalence and patterns of physical activity among medical students in Bangalore, India. Elect physic. 2013; 5(1): 606-610.

16. Angyán L, Téczely T, Mezey B, Lelovics Z. Selected physical characteristics of medical students. Med Educ. 2003; 8:1-6.

17. Dąbrowska-Galas M, Plinta R, Dąbrowska J, Skrzypulec-Plinta V. Physical activity in students of the Medical University of Silesia in Poland. Physical Therapy. 2015; 93(3): 384-392.

18. Stasiołek E, Jegier A. Physical activity in medical students. Med News. 2003; 72:140-142.

19. Kapka-Skrzypczak L, Bergier B, Diatczyk J, Niedźwiecka J, Biliński P, Wojtyła A. Dietary habits and body image perception among Polish adolescents and young adults-a population based study. Ann Agric Environ Med. 2012; 19(2): 299-308.

20. Krzych Ł. Analiza stylu życia studentów Śląskiej Akademii Medycznej. Zdr Publ. 2004; 114(1): 67-70.

21. Medrela-Kuder E. Zainteresowanie problematyka żywienia przez studentów krakowskiej Akademii Wychowania Fizycznego. Żyw Człow Metab. 2003; 30: 1-2.

22. Tsos A, Bergier B, Bergier J. Physical activity, physical development and eating habits within the lifestyles of students from Ukraine. Health Problems of Civilization. 2014; 8(4): 46-53.

23. Skibniewska KA, Radzymińska M, Jaworska MM, Babicz-Zielińska E. Badania zwyczajów żywieniowych studentów polskich i belgijskich. Żywność. Nauka. Technologia. Jakość. 2009; 4(65): 250-258.

24. Butler SM, Black DR, Blue CL, Gretebeck RJ. Change in diet, physical activity, and body weight in female college freshman. An J Health Behav. 2004; 24-32. 
25. Hajhosseini L, Holmes T, Mohamadi P, Goudarzi V, McProud L, Hollenbeck CB. Changes in body weight, body composition and resting metabolic rate (RMR) in first-year University freshman students. J Am Coll Nutr. 2006; 25: 123-127.

26. Huang TK, Harris KJ, Lee RE, Nazir N, Born W, Kaur H. Assessing overweight, obesity, diet and physical activity in college students. Jam Coll Health. 2003; 52: 83-86.

27. LaCaille L, Dauner KN, Krambeer RJ, Pedersen J. Psychosocial and Environmental Determinants of eating behaviors, physical activity, and weight change among college students: a qualitative analysis. J Am College Health. 2011; 59(6): 531-538.

28. Chaix B, Kestens Y, Duncan S, Merrien C, Thierry B, Pannier B, et al. Active transportation and public transportation use to achieve physical activity recommendations? A combined GPS, accelerometer, and mobility survey study. Int J Beh Nut Phys Activity. 2014; 11. doi:10.1186/ s12966-014-0124-x.

29. El Ansari W, Khalil K, Crone D, Stock C. Physical activity and gender differences: Correlates of compliance with recommended levels of five forms of physical activity among students at nine universities in Libya. Central European J Public Health. 2014; 22: 98-105.

30. Tsos A, Kasarda O, Pantik V. Female students at higher educational institutions in Ukraine and their level of physical activity. Health Problems of Civilization. 2017; 11(3): 158-162.

31. Leung CW, Ding EL, Catalano PJ, Villamor E, Rimm EB, Willett WC. Dietary intake and dietary quality of low-income adults in the Supplemental Nutrition Assistance Program. Am J Clin Nut. 2012; 96(5): 977-988.

32. Bergier B, Bergier J, Tsos A. Zachowania żywieniowe a aktywność fizyczna studentów ukraińskich. In: Stemplewski R, Szeklicki R, Maciaszka J., editors. Aktywność fizyczna i żywienie - w trosce o zdrowie i jakość życia. Poznań: Bogucki Wydawnictwo Naukowe; 2015 (in Polish).

33. Yahia N, Wang D, Rapley M, Dey R. Assessment of weight status, dietary habits and beliefs, physical activity, and nutritional knowledge among university students. 2015; 28: 112.
34. Storey KE, Forbes LE, Fraser SN, Spence JC, Plotnikoff RC, Raine KD, et al. Diet quality, nutrition and physical activity among adolescents: the Web-SPAN (Web-Survey of Physical Activity and Nutrition) project. Public Health Nutr. 2009; 12(11): 17.

35. Shani D, Nimbalkar A, Phatak A, Nimbalkar S. Training in Dietary Practices and Physical Activity to Improve Health among South Asian Medical Students. Advances in Preventive Medicine. 2014; http://dx.doi. org/10.1155/2014/610180.

36. Suliburska J, Bogdański P, Pupek-Musialik DM, Krauss H, Piątek J. Analysis of lifestyle of young adults in the rural and urban areas. Ann Agric Environ Med. 2012; 19(1): 135-139.

37. Rębacz-Maron E, Pawlak M, Michnik K. Stan odżywienia i aktywność fizyczna wśród studentek Uniwersytetu Szczecińskiego. Hygeia Public Health. 2013; 94(2): 371-377.

38. Biernat E. Aktywność fizyczna mieszkańców Warszawy. Na przykładzie wybranych grup zawodowych. 2011. Szkoła Główna Handlowa.

39. Biernat Biernat E, Lubowiecki-Vikuk AP. Socio-demographic determinants of leisure time physical inactivity of adolescents from the voivodeships of central Poland. Cent Eur J Sport Sci Med. 2017; 17(1): 43-52.

40. Soguksu K. Physical activity level between Polish and Turkish university students (IPAQ). In: Bergier B., editor. Physical activity in health and disease. Pope John Paul II State School of Higer Education in Biała Podlaska. 2011: 19-27.

41. Rasińska R. Nawyki żywieniowe studentów w zależności od płci. Nowiny Lekarskie. 2012; 81(4): 354-359.

42. Szponar B, Krzyszycha R. Ocena sposobu żywienia studentów Uniwersytetu medycznego w Lublinie w roku akademickim 2007-2008. Bromat. Chem. Toksykol. 2009; XLII, 2: 111-116.

43. Falkowska M. Raport CBOS- komunikat z badań: nawyki żywieniowe i upodobania kulinarne Polaków - październik 2000. www.cbos.pl, 17.11.2007.

44. Biały K. Raport CBOS- komunikat z badań: Dbałość o własna sylwetkę - październik 2003. www.cbos.pl, 22.06.2007.

45. Bergier J, Bergier B, Tsos A. Physical activity and eating habits among female students from Ukraine. Health Probl Civilizat. 2015; 9(2): 5-12. 